\title{
Chemotypes and antibacterial activity of Matricaria pubescens of Algeria
}

\author{
NOUR ELHOUDA MEKHADMI ${ }^{1,2}$, MESSAOUD RAMDANI ${ }^{1, \bullet}$, TAKIA LOGRADA ${ }^{1}$, PIERRE CHALARD ${ }^{3}$, \\ GILLES FIGUEREDO ${ }^{4}$ \\ ${ }^{1}$ Laboratory of Natural Resource Valorisation, SNV Faculty, Setif 1 University, 19000 Setif, Algeria. Tel. +213 658 101010, ^email: \\ ramdanimessoud@yahoo.com. \\ ${ }^{2}$ Department of Biology, Faculty of Natural Science and Life, University of El Oued, BP 789 El-Oued (39000) Algeria \\ ${ }^{3}$ Université Clermont Auvergne, CNRS, SIGMA Clermont, ICCF, F-63000 Clermont-Ferrand, France. \\ 4 LEXVA Analytique, 460 rue du Montant, 63110 Beaumont, France.
}

Manuscript received: 27 September 2019. Revision accepted: 10 October 2019.

\begin{abstract}
Mekhadmi NE, Ramdani M, Lograda T, Chalard P, Figueredo G. 2019. Chemotypes and antibacterial activity of Matricaria pubescens of Algeria. Biodiversitas 20: xxxx. The objectives of this study were to determine the chemical composition and to evaluate the antibacterial activity of Matricaria pubescens L. essential oils from 14 sampling locations in southern Algeria. The extraction of essential oils was carried out by the hydro-distillation; the analysis of chemical composition of essential oil was carried out by GC-MS. Antibacterial activity was performed by disc diffusion method at the undiluted and diluted essential oil (1/1, 1:2, 1:4 and 1:8 v:v of DMSO) against eight species of bacteria (Bacillus cereus, Escherichia coli, Klebsiella pneumoniae, Listeria innocua, Proteus mirabilis, Pseudomonas aeruginosa, Salmonella enterica and Staphylococcus aureus). The results showed that the average yields of essential oils were $0.4 \pm 0.27 \%$. A total of 34 components were identified, averaging $99.22 \pm 0.8 \%$ of the total oils. The main components were $\beta$ ocimene $(\mathrm{Z})(47.41 \pm 13.67 \%), \alpha$-pinene $(19 \pm 7.36 \%)$, $\beta$-bulnesene $(4.96 \pm 10.6 \%)$, ocimene-allo $(4.46 \pm 1.3 \%), 1$-phenyl-penta- 2,4 diyne $(4.06 \pm 5.7 \%)$, limonene $(3.84 \pm 1.8 \%)$, caryophyllene oxide $(2.36 \pm 3.6 \%)$ and $\gamma$-bisabolene-E $(2.08 \pm 4.3 \%)$. Based on the UPGMA cluster analysis, there were two distinct clades of $M$. pubescens. This species has a chemical polymorphism with different chemotypes marked in nature. There were four chemotypes identified in the essential oil of $M$. pubescens in the region studied. The essential oil of $M$. pubescens has antibacterial activity against eight bacteria tested in a concentration-dependent manner.
\end{abstract}

Keywords: Algeria, antibacterial activity, chemotypes, essential oils, Matricaria pubescens

\section{INTRODUCTION}

Matricaria pubescens (Desf.) Sch. Bip. (Asteraceae) is an endemic species in North Africa, locally known as "Garetoufa" (Ozenda 2004). Its synonyms are Chlamydophora pubescens Coss. \& Kra. and Cotula pubescens Desf (Reyes-Betancort 2003). It is found in steppe and desert pastures (Benhouhou 2005).

M. pubescens is very popular in traditional medicine (Ould El-Hadj et al. 2003; Bouallala et al. 2014). It is used to treat eye diseases, itching, inflammation of wounds, diseases of the female genital tract and bronchopulmonary diseases (Maiza et al. 1995, 2011, Hammiche et al. 2006), digestive disorders, internal tumors, rheumatism and neuralgia (Djellouli et al. 2013). Analysis of the aerial parts of $M$. pubescens revealed the presence of two coumarins and an isobutyl amide (Benkiki 2006). The aqueous extracts of the aerial part showed the presence of alkaloids, saponins, flavonoids, and terpenes (Gherboudj et al. 2012; Makhloufi et al. 2012).

Chemical analysis of essential oils of $M$. pubescens collected from the Ghardaia region shows the presence of ethyl isochrysanthemoate, spathulenol, $\alpha$-cadinol, and geranyl isovalerate as major components (Boutaghane et al. 2011; Tadrent et al. 2016). The investigation of the essential oil of $M$. pubescens collected from the Biskra region showed that the major compounds were spathulenol, elemicine and herniarine (Bouzaine 2015), while study by Makhloufi et al. (2014) showed that the essential oil of $M$. pubescens in the Bechar region is rich in $\beta$-ocimene-(Z), myrcene and $\alpha$-pinene (Table 1). Two species of $M$. pubescens and $M$. chamomilla, are morphologically similar, but they differ in essential oils composition (Tadrent et al. 2016). It is possible to obtain different composition of essential oils in the same species and morphologically identical individuals, which is known as chemotypes or chemical race. A chemotype is generally indicated by its principal components, which is indicated by the letters "ct" (Deschepper 1990).

A study by Makhloufi et al. (2012) showed that the essential oil of $M$. pubescens has potent antibacterial activity against $E$. coli, B. cereus, and $S$. aureus. Bouzaine et al. (2011) showed that E. cloacae and E. faecalis were significantly sensitive to aqueous extracts of $M$. pubescens (Bouzaine et al. 2016). The aqueous, methanolic, ethanolic and acetonic extracts have antibacterial activity against $S$. aureus and E. coli (Metrouh-Amir et al. 2015).

The aim of this study is to identify the chemical composition of essential oils of M. pubescens from Algeria and evaluates its antibacterial activities. 


\section{MATERIALS AND METHODS}

\section{Plant materials}

Matricaria pubescens is an annual plant, can reach 1.5 $\mathrm{m}$ in height. The stem is erect, a rower with alternate leaves; sessile, thick and fleshy (Figure 1). The flowers, yellow in the center, white at the circumference, very fragrant, are grouped in solitary heads at the top of the branches. The fruit is very small, yellowish-white, slightly arched (Quézel and Santa 1963). Samples of M. pubescens were collected in the flowering stage, of 14 localities in southern Algeria (Figure 2).

The geographical features of the populations sampled are summarized in Table 2. Aerial parts were collected in March 2017. The air-dried materials were subjected to hydrodistillation for $3 \mathrm{~h}$ using a Clevenger apparatus type. Voucher specimens were deposited in the herbarium of the Department of Ecology and Biology, Setif University, Algeria. The oil obtained was collected and dried over anhydrous sodium sulfate and stored at $4^{\circ} \mathrm{C}$ in sealed brown vials until use.

Table 1. Chemical composition of essential oil of Matricaria pubescens and M. chamomilla

\begin{tabular}{|c|c|c|c|c|c|c|c|c|c|c|c|c|c|c|c|c|c|}
\hline \multirow[b]{3}{*}{$\begin{array}{l}\text { Country } \\
\text { References* }\end{array}$} & \multicolumn{13}{|c|}{ Matricaria chamomilla } & \multicolumn{4}{|c|}{ Matricaria pubescens } \\
\hline & \multirow[b]{2}{*}{ 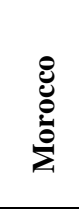 } & \multirow[b]{2}{*}{$\underset{\overrightarrow{0}}{\overrightarrow{0}}$} & \multirow[b]{2}{*}{ 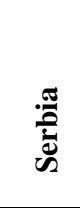 } & \multirow[b]{2}{*}{$\stackrel{\vec{\Xi}}{\Xi}$} & \multirow[b]{2}{*}{ } & \multicolumn{8}{|c|}{ Iran } & \multicolumn{4}{|c|}{ Algeria } \\
\hline & & & & & & 1 & $\mathbf{A}$ & 3 & 4 & 5 & 6 & 7 & 8 & שَّ & שֶّ & $\begin{array}{l}\frac{\pi}{20} \\
\frac{\pi}{0} \\
C \\
C\end{array}$ & 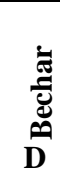 \\
\hline$\alpha$-pinene & 0.0 & 0.0 & 0.0 & 0.0 & 0.0 & 0.0 & 0.0 & 0.0 & 0.0 & 0.0 & 0.0 & 0.0 & 0.0 & 0.0 & 0.0 & 0.0 & 7.7 \\
\hline Myrcene & 0.0 & 0.0 & 0.0 & 0.0 & 0.0 & 0.0 & 0.0 & 0.0 & 0.0 & 0.0 & 0.0 & 0.0 & 0.0 & 0.0 & 0.0 & 0.0 & 15.2 \\
\hline$\Delta 3$-carene & 0.0 & 0.0 & 0.0 & 0.0 & 0.0 & 0.0 & 0.0 & 0.0 & 0.0 & 0.0 & 0.0 & 0.0 & 0.0 & 9.2 & 0.0 & 0.2 & 0.0 \\
\hline Limonene & 0.0 & 0.0 & 0.0 & 0.0 & 0.0 & 0.0 & 0.0 & 0.0 & 0.0 & 0.0 & 0.0 & 0.0 & 0.0 & 0.0 & 0.0 & 0.0 & 3.2 \\
\hline 1,8-Cineol & 9.2 & 0.0 & 0.2 & 0.0 & 56.9 & 0.0 & 0.0 & 0.0 & 0.0 & 0.0 & 0.0 & 0.0 & 0.0 & 0.0 & 0.0 & 0.0 & 1.4 \\
\hline$\beta$-ocimene (Z) & 0.0 & 0.0 & 1.7 & 0.0 & 0.0 & 0.0 & 0.0 & 0.0 & 0.0 & 0.0 & 0.0 & 0.0 & 0.0 & 0.0 & 0.0 & 0.0 & 53.8 \\
\hline$\beta$-ocimene $(\mathrm{E})$ & 0.0 & 0.0 & 1.9 & 0.0 & 0.0 & 0.0 & 0.0 & 0.0 & 0.0 & 0.0 & 0.0 & 0.0 & 0.0 & 0.0 & 0.0 & 0.0 & 3.2 \\
\hline Endobornyl acetate & 0.0 & 3.6 & 0.0 & 0.0 & 0.0 & 0.0 & 0.0 & 0.0 & 0.0 & 0.0 & 0.0 & 0.0 & 0.0 & 0.0 & 26.5 & 0.0 & 2.0 \\
\hline$\beta$-caryophyllene & 0.0 & 0.0 & 0.0 & 0.0 & 0.0 & 0.0 & 0.0 & 0.0 & 0.0 & 0.0 & 0.0 & 0.0 & 7.5 & 0.0 & 0.0 & 0.0 & 1.5 \\
\hline Herniarine & 0.0 & 0.0 & 0.0 & 0.0 & 0.0 & 0.0 & 0.0 & 0.0 & 0.0 & 0.0 & 0.0 & 0.0 & 0.0 & 0.0 & 0.0 & 16.9 & 0.0 \\
\hline$\beta$-Farnesene (Z) & 0.0 & 0.0 & 43.5 & 22.1 & 0.0 & 5.2 & 0.0 & 0.0 & 0.0 & 0.0 & 0.0 & 0.0 & 0.0 & 0.0 & 0.0 & 0.0 & 0.0 \\
\hline$\beta$-Farnesene (E) & 12.5 & 34.6 & 0.0 & 0.0 & 0.0 & 0.0 & 24.2 & 11.5 & 4.4 & 0.0 & 2.7 & 0.0 & 0.0 & 0.9 & 0.0 & 0.0 & 0.2 \\
\hline Sapathulenol & 0.0 & 0.0 & 0.0 & 0.0 & 0.0 & 9.4 & 0.4 & 0.0 & 0.0 & 0.0 & 0.0 & 0.0 & 0.0 & 3.6 & 19.4 & 4.8 & 0.5 \\
\hline$\gamma$-bisabolene $(\mathrm{E})$ & 0.0 & 0.0 & 8.5 & 0.0 & 0.0 & 0.0 & 0.0 & 0.0 & 0.0 & 0.0 & 0.0 & 0.0 & 0.0 & 0.0 & 0.0 & 0.0 & 0.0 \\
\hline$\alpha$-bisabolol & 0.0 & 0.0 & 0.0 & 2.2 & 0.0 & 5.0 & 7.3 & 7.3 & 0.0 & 0.0 & 0.0 & 0.0 & 0.0 & 0.0 & 0.0 & 0.0 & 0.2 \\
\hline$\alpha$-bisabolol oxide A & 0.0 & 32.5 & 8.5 & 48.7 & 0.0 & 21.5 & 10.2 & 0.0 & 0.0 & 41.0 & 53.0 & 25.0 & 15.5 & 15.4 & 0.0 & 0.0 & 0.0 \\
\hline$\alpha$-bisabolol oxide B & 0.0 & 8.8 & 9.0 & 9.8 & 0.0 & 7.0 & 5.0 & 0.0 & 0.0 & 0.0 & 9.9 & 9.4 & 2.1 & 23.2 & 0.0 & 0.0 & 0.0 \\
\hline$\alpha$-bisabololone oxide A & 0.0 & 7.4 & 6.0 & 6.7 & 0.0 & 10.0 & 0.2 & 0.0 & 0.0 & 0.0 & 5.2 & 0.0 & 62.4 & 10.0 & 0.0 & 0.0 & 0.0 \\
\hline Trans-trans farnesol & 0.0 & 0.0 & 0.0 & 0.0 & 0.0 & 0.0 & 0.0 & 17.0 & 66.0 & 0.0 & 0.0 & 0.0 & 0.0 & 0.0 & 0.0 & 0.0 & 0.0 \\
\hline Chamazylene & 25.2 & 0.9 & 5.6 & 2.8 & 0.0 & 4.2 & 0.0 & 2.6 & 0.0 & 21.0 & 4.3 & 0.0 & 2.1 & 3.8 & 0.0 & 0.0 & 0.0 \\
\hline Guaiazylene & 0.0 & 0.0 & 0.0 & 0.0 & 0.0 & 0.0 & 10.6 & 10.6 & 16.2 & 0.0 & 0.0 & 0.0 & 0.0 & 0.0 & 0.0 & 0.0 & 0.0 \\
\hline
\end{tabular}

Note: * A. Tadrent et al. (2016); B. Boutaghane et al. (2011); C. Bouzaine (2015); D. Makhloufi et al. (2014)

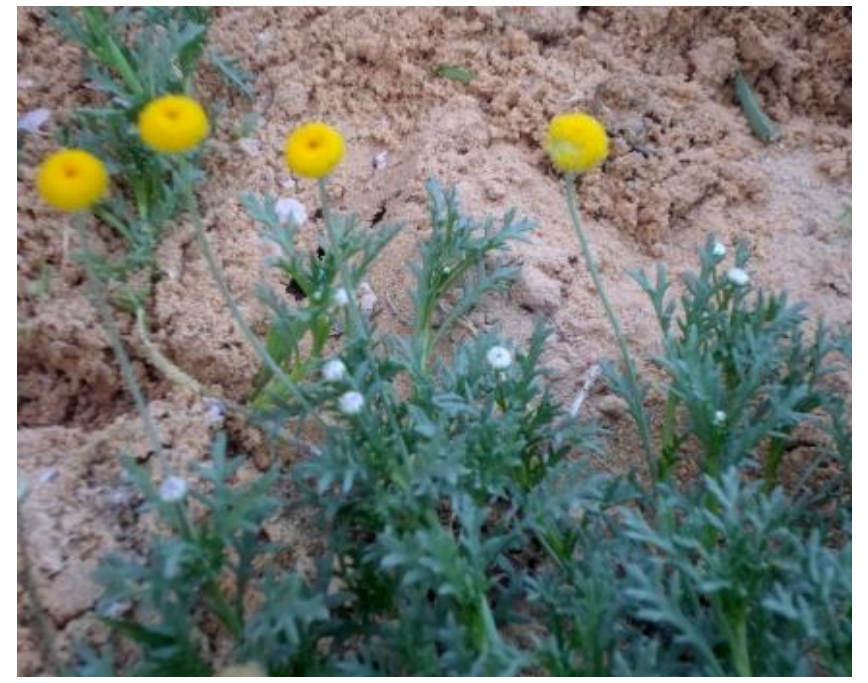

Figure 1. Matricaria pubescens from Ourgla region, Algeria

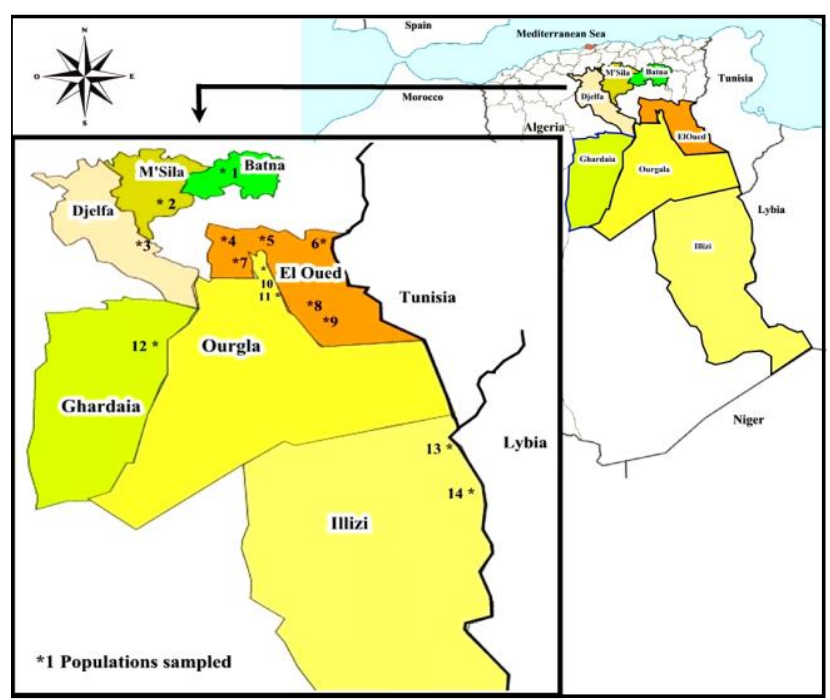

Figure 2. Location of Matricaria pubescens populations studied (the numbers, see Table 2) 
Table 2. Geographic coordinates of sampled populations

\begin{tabular}{|c|c|c|c|c|c|}
\hline \multirow{2}{*}{$\frac{\text { Provinces }}{\text { Batna }}$} & \multicolumn{2}{|c|}{ Populations } & \multirow{2}{*}{$\begin{array}{l}\text { Longitude (E) } \\
05^{\circ} 37^{\prime}\end{array}$} & \multirow{2}{*}{$\begin{array}{l}\text { Latitude }(\mathbf{N}) \\
35^{\circ} 36^{\prime}\end{array}$} & \multirow{2}{*}{$\begin{array}{l}\text { Altitude (m) } \\
767\end{array}$} \\
\hline & 1 & Oulad Slimane & & & \\
\hline M'Sila & 2 & Boussaâda & $04^{\circ} 10^{\prime}$ & $35^{\circ} 13^{\prime}$ & 606 \\
\hline Djelfa & 3 & Ras Elmiad & $04^{\circ} 26^{\prime}$ & $34^{\circ} 11^{\prime}$ & 394 \\
\hline El Oued & $\begin{array}{l}4 \\
5 \\
6 \\
7 \\
8 \\
9\end{array}$ & $\begin{array}{l}\text { El-M'ghair } \\
\text { Magrane } \\
\text { Beni Guecha } \\
\text { Djamaa } \\
\text { Hassi Khalifa } \\
\text { Mihouansa }\end{array}$ & $\begin{array}{l}05^{\circ} 55^{\prime} \\
06^{\circ} 57^{\prime} \\
07^{\circ} 20^{\prime} \\
05^{\circ} 59^{\prime} \\
07^{\circ} 01^{\prime} \\
06^{\circ} 42^{\prime}\end{array}$ & $\begin{array}{l}33^{\circ} 57^{\prime} \\
33^{\circ} 35^{\prime} \\
33^{\circ} 59^{\prime} \\
33^{\circ} 32^{\prime} \\
33^{\circ} 36^{\prime} \\
33^{\circ} 11^{\prime}\end{array}$ & $\begin{array}{l}02 \\
43 \\
09 \\
43 \\
42 \\
97\end{array}$ \\
\hline Ouargla & $\begin{array}{l}10 \\
11\end{array}$ & $\begin{array}{l}\text { Ben Nacer } \\
\text { Bakaar }\end{array}$ & $\begin{array}{l}06^{\circ} 24^{\prime} \\
06^{\circ} 24^{\prime}\end{array}$ & $\begin{array}{l}33^{\circ} 05^{\prime} \\
33^{\circ} 05^{\prime}\end{array}$ & $\begin{array}{l}100 \\
100\end{array}$ \\
\hline Ghardadia & 12 & El-Ménéa & $02^{\circ} 52^{\prime}$ & $30^{\circ} 35^{\prime}$ & 396 \\
\hline Illizi & $\begin{array}{l}13 \\
14 \\
\end{array}$ & $\begin{array}{l}\text { Dabdaab } \\
\text { In Aminaas }\end{array}$ & $\begin{array}{l}09^{\circ} 25^{\prime} \\
09^{\circ} 33^{\prime}\end{array}$ & $\begin{array}{l}29^{\circ} 58^{\prime} \\
28^{\circ} 02^{\prime}\end{array}$ & $\begin{array}{l}348 \\
553 \\
\end{array}$ \\
\hline
\end{tabular}

\section{Essential oil analysis}

The essential oils were analyzed on a Hewlett-Packard gas chromatograph CPG/FID 7890, coupled to a gas chromatograph: CPG/MS 7890/5975C, equipped with a

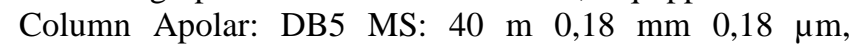
programming from $50^{\circ} \mathrm{C}$ for $5 \mathrm{~min}-5^{\circ} \mathrm{C} / \mathrm{min}$ until $300^{\circ} \mathrm{C}$. Helium was used as the carrier gas $(1.0 \mathrm{ml} / \mathrm{min})$; injection in split mode (1:30), injector and detector temperature is $280^{\circ} \mathrm{C}$ with split $1 / 100$. The mass spectrometer worked in EI mode at $70 \mathrm{eV}$; electron multiplier, $2500 \mathrm{~V}$; ion source temperature, $180^{\circ} \mathrm{C}$; MS data were acquired in the scan mode in the $\mathrm{m} / \mathrm{z}$ range 33-450. The identification of the components was based on the comparison of their mass spectra with those of NIST mass spectral library (Masada 1976; NIST 2002) and those described by Adams as well as on comparison of their retention indices either with those of authentic compounds or with literature values (Adams 2007).

\section{Antibacterial activity}

The antibacterial activities of the essential oil of $M$. pubescens were evaluated against three Gram-positive bacteria (Staphylococcus aureus ATCC2592, Listeria innocua CLIP 74915, Bacillus cereus ATCC 11778), five Gram-negative bacteria (Pseudomonas aeruginosa ATCC 27853, Klebsiella pneumoniae ATCC700603, Escherichia coli ATCC 25922, Proteus mirabilis ATCC35659 and Salmonella enterica CIP81-3. Bacterial inoculums were prepared from overnight broth culture in physiological saline $(0.8 \%$ of $\mathrm{NaCl})$ to obtain an optical density ranging from 0.08-01 at $625 \mathrm{~nm}$. Muller Hinton agar (MH agar) and MH agar supplemented with 5\% sheep blood for fastidious bacteria were poured in Petri dishes, solidified, and surface dried before inoculation. Sterile discs $(6 \mathrm{~mm})$ were placed on inoculated agars, by test bacteria, filled with $10 \mu 1$ of undiluted and diluted essential oil (1/1, 1/2, 1/4, 1/8 v/ $\mathrm{v}$ of DMSO). DMSO was used as a negative control, and four antibiotics were used as positive control (Gentamicin, Amoxicillin, Colistin 25 and Cefazolin 30).

Bacterial growth inhibition was determined as the diameter of the inhibition zones around the discs. All the tests were performed in triplicate, and the means were calculated as final results. The Petri dishes were incubated at $37^{\circ} \mathrm{C}$ for 18 to $24 \mathrm{~h}$ aerobically. After incubation, inhibition zone diameters were measured and documented (Dahiya and Purkayastha 2012; Nascimento et al. 2003). The sensitivity to the essential oil was classified by the diameter of the inhibition halos as follows: not sensitive (-) for diameter less than $8 \mathrm{~mm}$; sensitive (+) for diameter 9-14 $\mathrm{mm}$; very sensitive $(++)$ for diameter $15-19 \mathrm{~mm}$ and extremely sensitive (+++) for diameter larger than $20 \mathrm{~mm}$ (Ponce et al. 2003).

\section{Statistical analysis}

Data were first subjected to Principal Components Analysis (PCA) to examine the relationships among the terpenes compounds and identify the possible structure of the populations. Cluster analysis (UPGMA) was carried out on the original variables and on the Manhattan distance matrix to seek for hierarchical associations among the populations. The cluster analyses were carried out using Statistica v10 software. Statistical significance of antibacterial activity results were analyzed by the ANOVA three-way Completely Randomized (Populations, doses, and bacteria) by using the statistical software package (CoStat). All analyses are performed at the $5 \%$ significance level $(\mathrm{P}<0.05)$.

\section{RESULTS AND DISCUSSION}

\section{Essential oil yield and chemical composition}

The yields of $M$. pubescens essential oils were low, with an average of $0.4 \pm 0.27 \%$ ( $v / w)$. The highest yield is recorded in the essential oil of the El-Menea population $(0.92 \%)$, while the lowest yield is in the population (cultivar) of Ben Nacer $(0.06 \%)$. We note that a relationship exists between the essential oil yield of $M$. pubescens and the altitude (Figure 3 ). The regression line shows that the yield increases with altitude. 


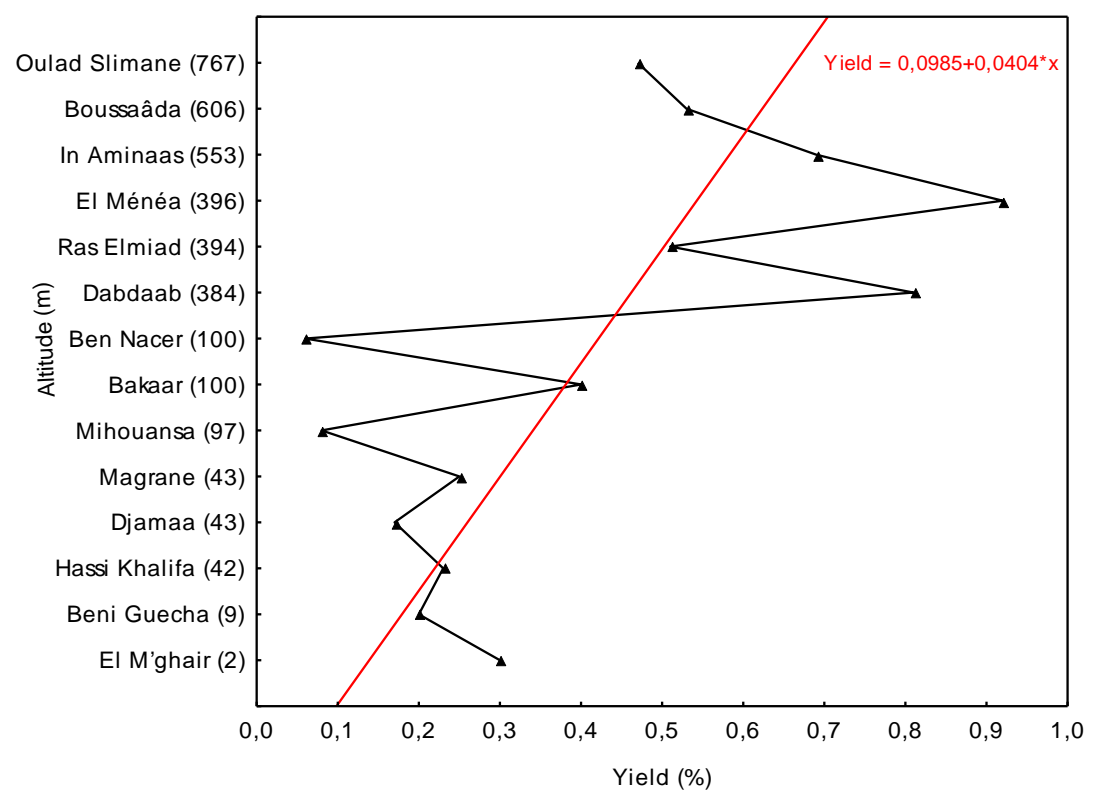

Figure 3. Variation of Matricaria pubescens yields by altitude
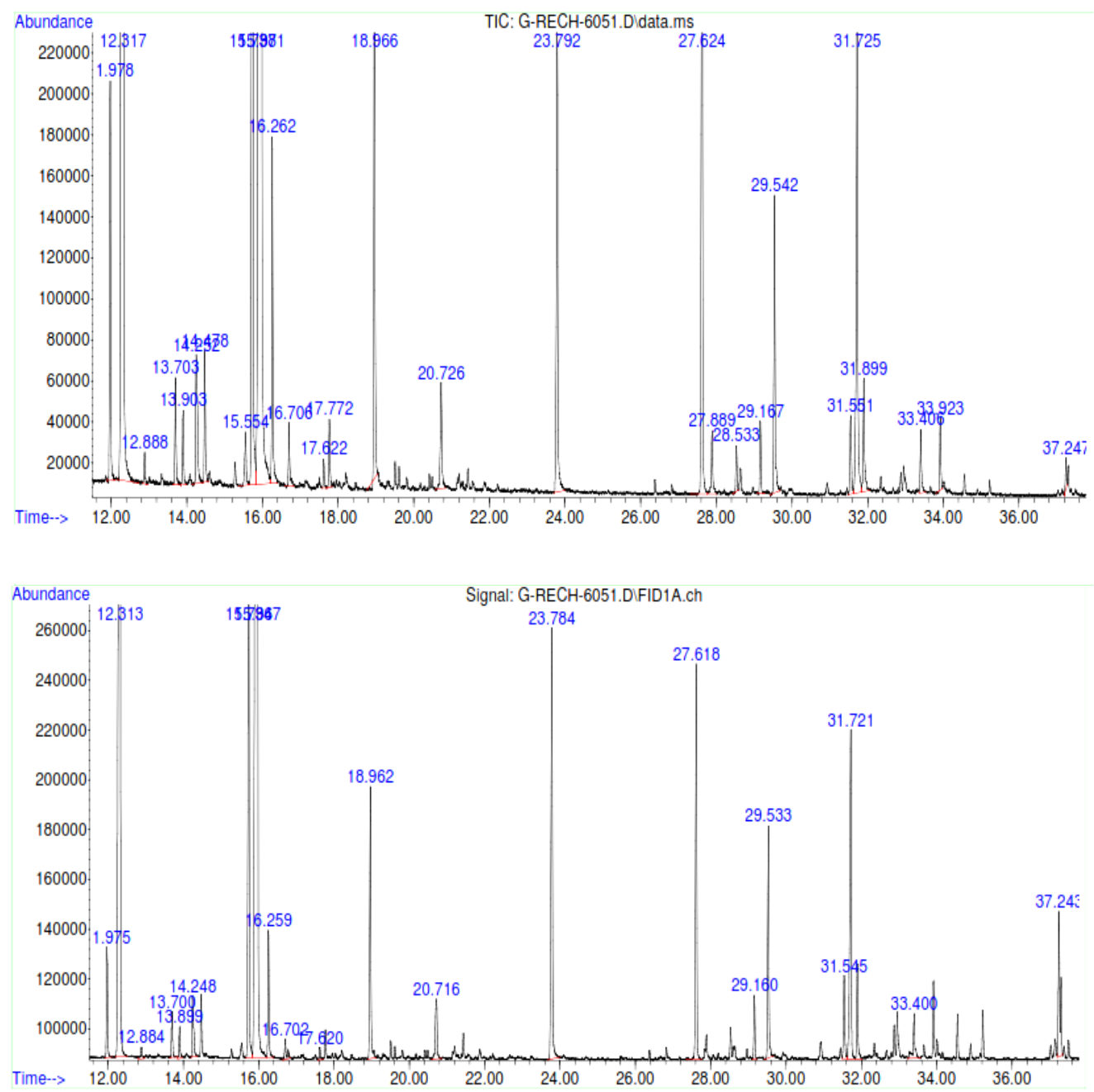

Figure 4. GC/Mass and GC/FID profiles of Matricaria pubescens (Boussaada population) 
Table 3. Chemical composition of Matricaria pubescens essential oils

\begin{tabular}{|c|c|c|c|c|c|c|c|c|c|c|c|c|c|c|c|c|c|}
\hline \multirow{2}{*}{$\begin{array}{l}\text { Provinces } \\
\text { Populations }\end{array}$} & & \multicolumn{6}{|c|}{ El Oued } & \multirow{2}{*}{ 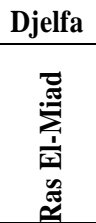 } & \multicolumn{2}{|c|}{ Illizi } & \multicolumn{2}{|c|}{ Ourgla } & \multirow{2}{*}{ 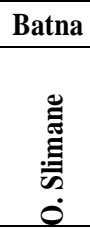 } & \multirow{2}{*}{ 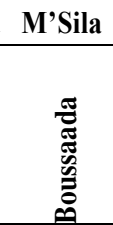 } & \multirow{2}{*}{ 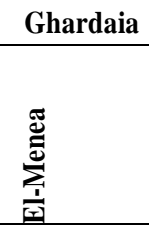 } & \multirow[b]{2}{*}{ 密 } & \multirow[b]{2}{*}{ คे } \\
\hline & & 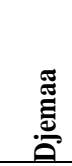 & 离 & 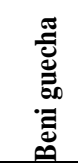 & 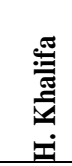 & 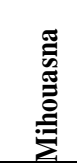 & 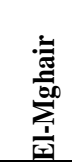 & & $\underset{\Xi}{\stackrel{\Xi}{E}}$ & $\begin{array}{l}\text { है } \\
\text { हूँ }\end{array}$ & 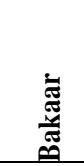 & 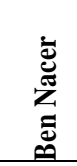 & & & & & \\
\hline Yields $(\%)$ & & 0.17 & 0.25 & 0.2 & 0.23 & 0.08 & 0.3 & 0.51 & $0 . \overline{69}$ & 0.81 & $0 . \overline{40}$ & $\overrightarrow{0.06}$ & 0.47 & 0.53 & 0.92 & 0.4 & 0.27 \\
\hline Number of compounds & KI & 21 & 15 & 20 & 16 & 21 & 21 & 17 & 22 & 17 & 19 & 30 & 20 & 22 & 23 & 20 & 4 \\
\hline Total $(\%)$ & & 99.87 & 99.68 & 99.37 & 99.34 & 99.25 & 99.65 & 97.62 & 99.88 & 99.79 & 99.65 & 97.09 & 99.27 & 99.54 & 99.04 & 99.22 & 20.80 \\
\hline$\alpha$-thujene & 921 & 0.00 & 0.00 & 0.25 & 0.99 & 1.38 & 0.11 & 0.17 & 6.72 & 1.99 & 0.88 & 1.20 & 0.17 & & 0.14 & 1 & 1.69 \\
\hline & 931 & 17.44 & +11.20 & 14.57 & 18.12 & 22.73 & 23.17 & 20.91 & 34.31 & 29.91 & 18.67 & 9.87 & 13.50 & & .90 & 19.02 & 27.09 \\
\hline Car & 946 & 0.19 & 0.12 & 0.23 & 0.00 & 0.21 & 0.32 & 0.22 & 0.00 & 0.80 & 0.13 & 0.33 & 0.12 & 0.24 & 0.17 & 0.22 & 0.18 \\
\hline $\mathrm{Sab}$ & 968 & 0.00 & 0.00 & 0.00 & 0.55 & 0.53 & 0.19 & 0.29 & 1.62 & 0.00 & 0.46 & 0.47 & 0.23 & 0.2 & & 0.34 & 0.40 \\
\hline$\beta$-pin & & 0.17 & 0.00 & 0.00 & 0.33 & 0.37 & 0.38 & 0.30 & 0.75 & 0.80 & 0.21 & 0.31 & 0.14 & & & 0.30 & 0.23 \\
\hline & & 0.46 & 0.51 & 0.60 & 0.77 & 0.96 & 1.17 & 0.49 & 0.65 & 0.00 & 0.44 & 0.28 & 0.50 & & & 0.55 & 0.27 \\
\hline & 001 & 0.22 & 0.00 & 0.38 & 0.00 & 0.00 & 0.21 & 0.00 & 0.00 & 0.80 & 0.00 & 0.22 & 0.12 & 0.0 & & 0.14 & 0.22 \\
\hline & 12 & 0.00 & 0.00 & 0.00 & 0.00 & 0.00 & 0.00 & 0.00 & 0.00 & 0.00 & 0.00 & 0.23 & 0.07 & 0.0 & & 0.02 & 0.06 \\
\hline & & 0.00 & 0.00 & 0.00 & 0.44 & 0.37 & 0.26 & 0.00 & 0.37 & 0.00 & 0.19 & 0.43 & 0.27 & 0.2 & & 0.20 & 0.16 \\
\hline & & 3.28 & 2.40 & 4.09 & 5.86 & 7.29 & 5.30 & 4.68 & 2.54 & 6.38 & 2.43 & 2.69 & 1.88 & & & 3.84 & 1.69 \\
\hline$\beta-\mathrm{ph}$ & & 0.32 & 0.00 & 0.00 & 0.00 & 0.00 & 1.65 & 0.13 & 0.07 & 0.00 & 0.00 & 0.33 & 0.00 & & & 0.18 & 0.42 \\
\hline$\beta$-oci & & 52.48 & 36.04 & 44.10 & 41.10 & & & 57.46 & 33.80 & 24.73 & 48.70 & 25.69 & 71.00 & & & 47.41 & 13.26 \\
\hline$\beta$-oci & & 1.89 & 1.21 & & & & 3.10 & & 0.84 & & 1.30 & 1.29 & & & & 1.87 & 0.77 \\
\hline & & & & & & & & & & & 0.09 & 0.19 & & & & 0.083 & 30.12 \\
\hline Terp & & & & & & & & & & & 0.00 & 0.22 & & & & 0.05 & 0.08 \\
\hline $\begin{array}{l}\text { 3-methyl-2 } \\
\text { (2-methyl butenyl) fura }\end{array}$ & 1085 & 0.14 & 0.00 & 0.00 & 0.00 & 0.14 & 0.00 & 0.00 & 0.00 & 0.00 & 0.00 & 0.25 & 0.00 & 0.14 & 0.18 & 0.06 & 0.09 \\
\hline $\begin{array}{l}\text { Butanoic } \\
\text { methylb }\end{array}$ & 1098 & 0.00 & 0.00 & 0.00 & 0.00 & 0.00 & 0.00 & 0.00 & 0.00 & 0.00 & 0.00 & 0.14 & 0.00 & 0.16 & 0.00 & 0.02 & 0.05 \\
\hline & & & 3.73 & & 3.43 & 3.56 & & & 2.79 & 2.39 & 4.23 & 4.04 & & & & & 1.27 \\
\hline & & 0.32 & 0.00 & 0. & 0.00 & 1.17 & 0.00 & 0.00 & 0.00 & 0.80 & 0.00 & 1.07 & 0. & & & .27 & 0.42 \\
\hline & & 0.00 & 0.00 & 0.00 & 0.00 & 0.00 & 0.00 & 0.00 & 0.77 & 0.86 & 0.00 & 0.42 & 0. & & & .20 & 0.30 \\
\hline & & 0.17 & 0.00 & 0.39 & 0.00 & 0.00 & 0.43 & 0.44 & 0.00 & 2.39 & 0.00 & 0.82 & 0.23 & 0. & 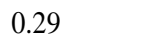 & 0.40 & 0.62 \\
\hline $1-$ & & 0.00 & 15.20 & 0.00 & 8.40 & 5.54 & 0.00 & 0.00 & 3.18 & 9.50 & 15.05 & 0.00 & 0.00 & 0.0 & & 4.06 & 5.74 \\
\hline & & 0.00 & 0.00 & 0.00 & 0.00 & 0.00 & 0.36 & 0.00 & 0.47 & 0.00 & 0.33 & 0.00 & 0.00 & 0. & & 0.20 & 0.20 \\
\hline & & 1.48 & 2.50 & 4.09 & 2.54 & 3.90 & 1.47 & 1.15 & 2.70 & 1.92 & 2.05 & 0.45 & 1.10 & 1.2 & & 2.10 & 1.04 \\
\hline & & 0.00 & 0.84 & 0.30 & 0.00 & 0.00 & 0.00 & 0.00 & 0.57 & 0.91 & 0.29 & 0.00 & 0.04 & 0.0 & & 2.21 & 0.33 \\
\hline & & 0.61 & 2.07 & & 0.99 & 0.26 & 1.75 & 0.44 & 0.85 & 0.00 & 1.00 & 0.00 & 0.76 & 1.2 & & 0.84 & 0.63 \\
\hline & & 0.29 & 0.00 & 0.78 & 0.00 & 0.00 & 0.77 & 0.37 & 0.00 & 1.31 & 0.00 & 0.26 & 0.31 & 0. & & 0.33 & 0.40 \\
\hline & & 0.00 & 12.74 & 0.60 & 11.49 & 0.00 & 0.51 & 0.00 & 0.00 & 0.00 & 2.89 & 0.11 & 0.12 & 0.6 & & 2.08 & 4.32 \\
\hline & & 2.28 & 0.00 & 2.30 & 1.66 & 1.17 & 0.00 & 2.40 & 1.27 & 0.00 & 0.00 & 0.81 & 0.00 & 0.2 & & 0.95 & 0.93 \\
\hline & & 2.40 & 0.00 & 1.86 & 1.33 & 5.38 & 0.00 & 0.00 & 4.16 & 13.50 & 0.00 & 2.75 & 0.00 & 0.1 & & 2.36 & 3.62 \\
\hline & & 0.7 & 0.18 & 1.45 & 0.00 & 0.00 & 0.00 & 0.00 & 0.00 & 0.00 & 0.00 & 1.41 & 0.00 & & & 0.35 & 0.52 \\
\hline & & & 0.16 & & & & 0.0 & & & & 0.00 & 1.35 & 0.00 & & & 0.21 & 0.38 \\
\hline & & 0.0 & 0.00 & 0.0 & 0.00 & & & & & & 0.00 & 0.98 & & & & 0.07 & 0.26 \\
\hline & 1668 & 8.47 & 0.77 & 15.40 & 0.00 & 0.27 & 0.00 & 0.00 & 0.67 & 0.00 & 0.33 & 38.50 & 0.00 & 3.01 & 1.96 & 4.95 & 10.60 \\
\hline & & & & & & & & & & & & & & & & & \\
\hline & & & & & & & & & & & & & & & & 83.75 & 512.18 \\
\hline & & 0.63 & 0.00 & 0.71 & 0.00 & 1.31 & 0.79 & 0.44 & 1.25 & 4.05 & 0.33 & 2.70 & & 0. & & 1.08 & 1.07 \\
\hline & & 13.14 & 18.92 & 24.87 & 16.69 & 5.60 & 4.51 & 4.35 & 6.06 & 4.14 & 6.57 & 41.10 & & & & 11.46 & 510.44 \\
\hline & & 2.93 & 0.16 & 1.86 & 1.33 & 5.65 & 0.00 & 0.15 & 4.63 & 13.50 & 0.00 & 4.10 & 0.00 & & & 2.57 & 3.55 \\
\hline Phenolic compounds & & 0.70 & 0.18 & 1.45 & 0.00 & 0.00 & 0.00 & 0.00 & 0.00 & 0.00 & 0.00 & 1.41 & 0.00 & 0.55 & 0.63 & 0.35 & 0.51 \\
\hline
\end{tabular}

The essential oil analysis of $M$. pubescens by GC-MS (Figure 4) has led to the identified 34 compounds, representing an average of $99.22 \pm 0.84 \%$ of the total oil. The relative abundance of the components of these essential oils is represented in order of their appearances (Table 3).

Chemical analysis of $M$. pubescens essential oil shows that the $\beta$-ocimene $(\mathrm{Z})$ was the major compound $(47.41 \pm$ $13.67 \%$ ), and the highest concentration is in the essential oil of the Oulad Slimane population (71\%), followed by $\alpha$ - pinene $(19 \pm 7.36 \%)$ and $\beta$-bulnesene $(4.96 \pm 10.6 \%)$, where the highest concentration $(38.50 \%)$ was found in the Ben Nacer population.

Other compounds are also present but at low levels, allo-ocimene $(4.46 \pm 1.27 \%)$, 1-phenyl-penta-2,4-diyne $(4.06 \pm 5.74 \%)$, limonene $(3.84 \pm 1.76 \%)$, caryophyllene oxide $(2.36 \pm 3.63 \%)$ and $\gamma$-bisabolene-E $(2.08 \pm 4.33 \%)$. The distribution of chemical classes in $M$. pubescens' essential oils is very heterogeneous (Figure 5). The monoterpene hydrocarbons with an average of $83.75 \pm$ 
$13.76 \%$ were mainly composed of $\beta$-ocimene-Z (47.41 \pm $13.76 \%)$ and $\alpha$-pinene $(19.02 \pm 7.35 \%)$. Oxygen monoterpenes with $1.08 \pm 1.11 \%$ are the least represented in the oil. The hydrocarbon sesquiterpenes are present in the oil with an average of $11.46 \pm 10.83 \%$, whereas the oxygenated sesquiterpenes are present at a low level.

The chemical composition of $M$. pubescens essential oils in the different studied populations shows very little difference. The principal component statistical analysis (PCA) of $M$. pubescens populations, based on chemical composition, shows the separation of the populations of Ben Nacer, Dabdab, In Amenas, O. Slimane, and ElMenea, the rest of the populations forms a more or less condensed cloud (Figure 6).

The result of UPGMA cluster analysis (Figure 7), based on linkage distance, separates populations into two distinct clades. The first clade is represented by the Ben Nacer population, which isolates itself with the presence of high level of $\alpha$-bulnesene (38.5\%) and low level of $\beta$-ocimene (Z) $(25.69 \%)$.

The second clade is subdivided into two subclades. The first sub-clade brings together the two populations of Dabdaab and In Aminas. This sub-clade represented by high levels of $\alpha$-pinene, $\beta$-ocimene (Z), and caryophyllene oxide. The second sub-clade is subdivided into two groups, this separation is based on the presence of 1-phenyl-penta2,4-diyne in the populations (Mihouansa, Hassi Khalifa, Bakaar and Magrene), while the second group is characterized by the presence of a significant rate of ocimene-allo and includes the stations (Beni Guecha, ElMenea, Ouled Slimane, Ras El-miaad, El-Meghair, and Djemaa). The statistical analysis of the chemical composition of essential oils, allowed us to highlight the presence of four chemotypes within the species $M$. pubescens from Algeria (Table 4).

\section{Antibacterial activity of $M$. pubescens essential oils}

Bacterial sensitivity to essential oils is determined by the diameter of the inhibitory zones. The M. pubescens essential oil has antibacterial activity against eight bacteria species tested (Table 5).

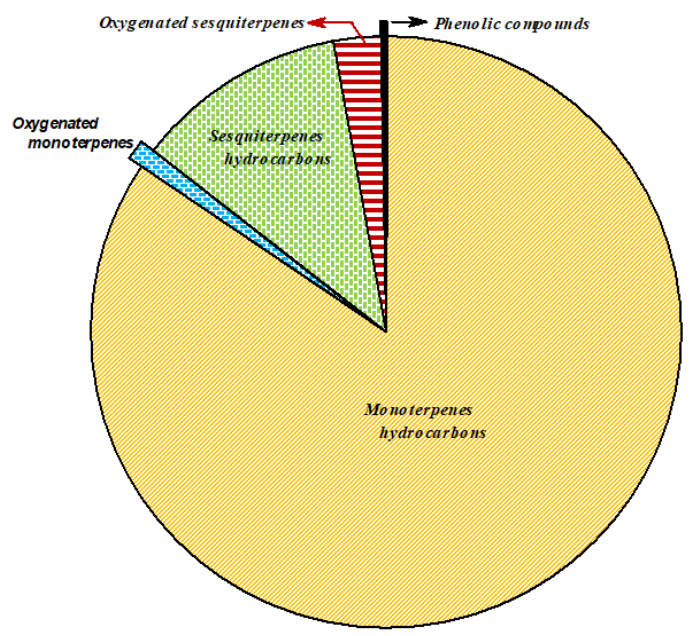

Figure 5. Chemical classes of Matricaria pubescens essential oil
The result of antibacterial assay of $M$. pubescens against several bacteria strains showed that $K$. pneumoniae ATCC 700603, P. mirabilis ATCC 35659, L. innocua CLIP 74915 and $S$. aureus ATCC 25923 were extremely sensitive, E. coli ATCC 25922 and B. cereus ATCC 11778 were susceptible, while $P$. aeruginosa ATCC 27853 was sensitive to the undiluted essential oil of M. pubescens. On the other hand, B. cereus ATCC 11778 and $P$. aeruginosa ATCC 27853 were not sensitive to the diluted (1/4) $M$. pubescens essential oils. Based on the result of statistical analysis, it showed that the interaction of sampling locations, dilution levels, and strain of bacteria were highly significant $(\mathrm{P}<0.001)$ (Table 6).

The three-way analysis of variance revealed a very significant difference in the diameters of the inhibitory zones among the essential oils dilutions. Gentamicin has the highest growth inhibition against several bacteria tested with the average inhibitory zone of $24.07 \mathrm{~mm}$, classified in the group a (Table 7).

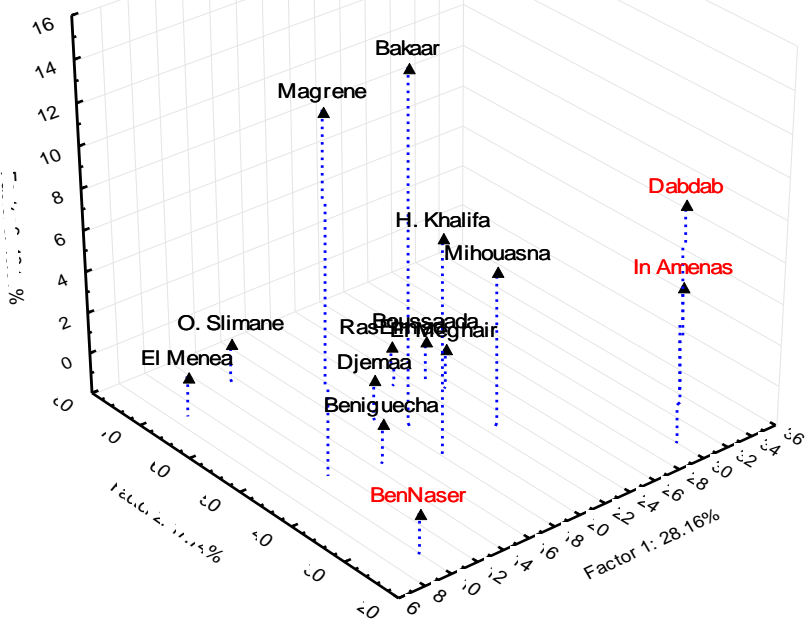

Figure 6. Spatial projection of Matricaria pubescens populations

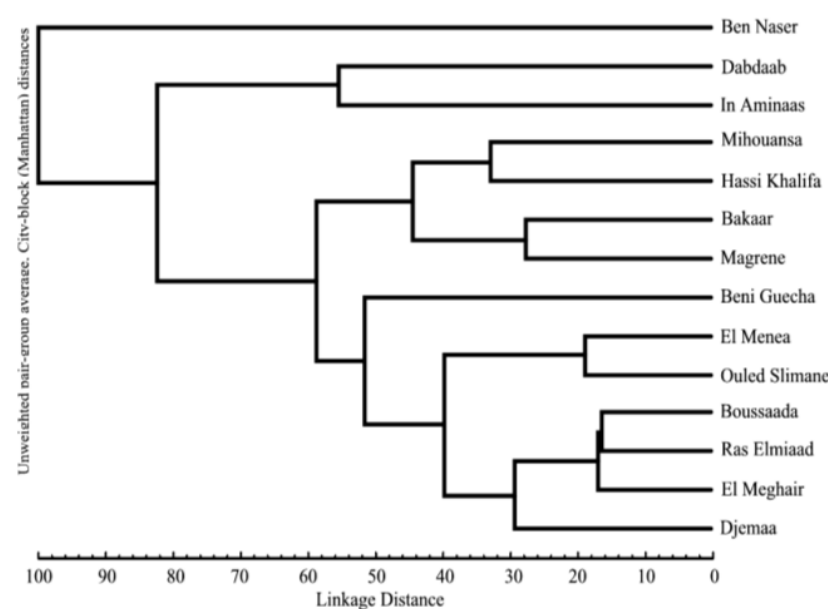

Figure 7. UPGMA of Matricaria pubescens populations 
Table 4. Chemotypes of Matricaria pubescens in Algeria

\begin{tabular}{lll}
\hline Chemotypes & Populations \\
\hline a & $\alpha$-bulnesene- $\beta$-ocimane (Z)- $\alpha$-pinene & Ben Nacer \\
b & $\alpha$-pinene- $\beta$-ocimane (Z)-Ocimene allo & Beni Gacha, Oulad Slimane, El-Ménéa, Djemaa, El-Meghair, Boussada \\
& & and Ras El-miaad \\
c & $\alpha$-pinene- $\beta$-ocimane (Z)-1-phenyl-penta-2,4-diyne & Mihouansa, Hassi Khalifa, Magrane and Bakaar \\
d & $\alpha$-pinene- $\beta$-ocimane (Z)-Caryophyllene oxide & In Aminaas and Dabdaab \\
\hline
\end{tabular}

Table 5. Antibacterial activity of Matricaria pubescens essential oil

\begin{tabular}{|c|c|c|c|c|c|c|c|c|c|}
\hline Stations & Dilution & E. coli & P. aeruginosa & S. aureus & K. pneumoniae & S. enterica & L. innocua & B. cereus & P. mirabilis \\
\hline \multirow{4}{*}{ Ben Nacer } & 1 & $14.3 \pm 0.57$ & $13 \pm 0$ & $47 \pm 0.3$ & $11.2 \pm 0.2$ & $9.1 \pm 0.1$ & $22.2 \pm 0.1$ & $12.9 \pm 0.1$ & $22 \pm 0$ \\
\hline & $1 / 2$ & $11.7 \pm 0.57$ & $8.2 \pm 0.8$ & $44.7 \pm 0.6$ & $9.2 \pm 0.2$ & 0 & $16.5 \pm 0.5$ & $11.2 \pm 0.3$ & $13.8 \pm 0.2$ \\
\hline & $1 / 4$ & $9.7 \pm 0.6$ & $7 \pm 0$ & $30 \pm 0$ & $7.3 \pm 0.5$ & 0 & $13.3 \pm 0.3$ & $10 \pm 0$ & 0 \\
\hline & $1 / 8$ & 0 & 0 & $16.8 \pm 0.4$ & 0 & 0 & $9.2 \pm 0.1$ & 0 & 0 \\
\hline \multirow{4}{*}{ Bakaar } & 1 & $16.6 \pm 0.2$ & $15.9 \pm 0.4$ & $35.5 \pm 0.9$ & $23 \pm 0$ & $25.4 \pm 0.5$ & $21 \pm 0$ & $14 \pm 0.1$ & $47.2 \pm 0.3$ \\
\hline & $1 / 2$ & $11 \pm 0$ & $14 \pm 0.5$ & $20.3 \pm 0.6$ & $15.9 \pm 0.1$ & $11 \pm 0$ & $14.8 \pm 0.8$ & $12 \pm 0$ & $29.2 \pm 0.3$ \\
\hline & $1 / 4$ & $9.7 \pm 0.6$ & $8 \pm 0$ & $8.7 \pm 0.6$ & $8.3 \pm 0.6$ & $8 \pm 0$ & $12 \pm 0$ & $10.3 \pm 0.6$ & $20 \pm 0$ \\
\hline & $1 / 8$ & $7.8 \pm 0.8$ & 0 & 0 & 0 & 0 & $10.2 \pm 0.3$ & $9 \pm 0$ & $10 \pm 0$ \\
\hline \multirow{4}{*}{ Magrane } & 1 & $17 \pm 0$ & $13.1 \pm 0.1$ & $44.3 \pm 0.6$ & $29.3 \pm 0.6$ & $17.3 \pm 0.6$ & $42 \pm 0$ & $15 \pm 0$ & $44.9 \pm 0.1$ \\
\hline & $1 / 2$ & $14.8 \pm 0.3$ & $10.3 \pm 0.6$ & $26.5 \pm 0.5$ & $23.7 \pm 1.2$ & $14 \pm 0$ & $28 \pm 0$ & $11 \pm 0$ & $29.8 \pm 1.1$ \\
\hline & $1 / 4$ & $13 \pm 0$ & $8 \pm 0$ & $14.93 \pm 0.1$ & $20 \pm 1.7$ & $12 \pm 0$ & $17 \pm 0$ & 0 & $16.7 \pm 0.6$ \\
\hline & $1 / 8$ & $8 \pm 0$ & $8 \pm 0$ & $10 \pm 0$ & $11 \pm 0$ & 0 & $13.5 \pm 0.9$ & 0 & $9.3 \pm 0.2$ \\
\hline \multirow{4}{*}{ Beni guecha } & 1 & $20 \pm 0$ & $10.5 \pm 0.5$ & $17.2 \pm 0.3$ & $10.4 \pm 0.5$ & $9.2 \pm 0.3$ & $15.2 \pm 2$ & $21 \pm 0$ & $10 \pm 0$ \\
\hline & $1 / 2$ & $14.5 \pm 0.9$ & $9.5 \pm 0$ & $13.2 \pm 0.3$ & 0 & 0 & $13.2 \pm 0.3$ & $13 \pm 0$ & $9.33 \pm 0.6$ \\
\hline & $1 / 4$ & $10.8 \pm 0.3$ & 0 & $9.2 \pm 0.3$ & 0 & 0 & $9 \pm 0$ & $10.7 \pm 1.2$ & 0 \\
\hline & $1 / 8$ & $9.3 \pm 0.6$ & 0 & $7.7 \pm 0.6$ & 0 & 0 & $7 \pm 0$ & $7 \pm 0$ & 0 \\
\hline \multirow{4}{*}{ Hassikhalifa } & 1 & $9.7 \pm 1.2$ & $29.5 \pm 0.5$ & $23 \pm 0$ & $12 \pm 0$ & $8.3 \pm 0$ & $39.3 \pm 0.6$ & $24 \pm 0.1$ & $42.7 \pm 0.6$ \\
\hline & $1 / 2$ & $9 \pm 0$ & $14.7 \pm 0.3$ & $19.5 \pm 0$ & $10.5 \pm 0.5$ & 0 & $29.8 \pm 1.4$ & $10 \pm 0$ & $28 \pm 0$ \\
\hline & $1 / 4$ & $7.8 \pm 0.8$ & $8 \pm 0$ & $16 \pm 0$ & $8.7 \pm 0.6$ & 0 & $14.05 \pm 0.1$ & 0 & $17 \pm 0$ \\
\hline & $1 / 8$ & $8 \pm 0$ & 0 & $11.8 \pm 1$ & $7.3 \pm 0.6$ & 0 & $10 \pm 0$ & 0 & $12 \pm 0$ \\
\hline \multirow{4}{*}{ Mihouansa } & 1 & $17.3 \pm 0.6$ & $13 \pm 0$ & $21.7 \pm 0.6$ & $22.5 \pm 1.3$ & $13 \pm 0$ & $33.7 \pm 1.5$ & $17 \pm 0$ & $41.7 \pm 1.2$ \\
\hline & $1 / 2$ & $12.3 \pm 0.6$ & $10 \pm 0$ & $17.5 \pm 0.9$ & $14.3 \pm 0.6$ & $9.2 \pm 1$ & $16 \pm 0.86$ & $13.7 \pm 1.2$ & $35 \pm 0$ \\
\hline & $1 / 4$ & $9.3 \pm 0.6$ & $7.8 \pm 0.3$ & $13.7 \pm 1.2$ & $11 \pm 0$ & $9 \pm 0$ & $10.2 \pm 0.3$ & 0 & $24.5 \pm 0.9$ \\
\hline & $1 / 8$ & $8 \pm 0$ & $7 \pm 0$ & $10.3 \pm 0.6$ & $8.3 \pm 1.2$ & 0 & $7.3 \pm 0.6$ & 0 & $19 \pm 0$ \\
\hline \multirow{4}{*}{ El m'ghair } & 1 & $13.8 \pm 1.3$ & $27.1 \pm 0.2$ & $20.3 \pm 0.6$ & $10.2 \pm 0.3$ & $11 \pm 0$ & $33 \pm 0$ & $13 \pm 0.5$ & $34.1 \pm 0.2$ \\
\hline & $1 / 2$ & $10.8 \pm 0.8$ & $12 \pm 0$ & $13 \pm 0$ & $9 \pm 0$ & $8 \pm 0$ & $24.3 \pm 0.6$ & $10 \pm 0$ & $19 \pm 0$ \\
\hline & $1 / 4$ & $10.1 \pm 0.2$ & 0 & $8.7 \pm 1.5$ & 0 & 0 & $11 \pm 0$ & 0 & $11.1 \pm 0.4$ \\
\hline & $1 / 8$ & $9 \pm 0$ & 0 & 0 & 0 & 0 & $9.3 \pm 0.6$ & 0 & 0 \\
\hline \multirow{4}{*}{ Djamaa } & 1 & $24 \pm 0$ & $13.8 \pm 0.3$ & $42 \pm 0$ & $40 \pm 1$ & $15.8 \pm 0.8$ & $18.3 \pm 0.6$ & $19.8 \pm 0.3$ & $51.3 \pm 1.2$ \\
\hline & $1 / 2$ & $13.3 \pm 0.3$ & $12 \pm 0$ & $23 \pm 0$ & $19.7 \pm 2.3$ & $14 \pm 0$ & $15 \pm 0$ & $12.8 \pm 0.7$ & $30 \pm 0$ \\
\hline & $1 / 4$ & $11 \pm 0$ & $11.3 \pm 0.3$ & $21 \pm 0$ & $18 \pm 0$ & $11.8 \pm 0.28$ & $13.6 \pm 0.5$ & $10.3 \pm 2.1$ & $23 \pm 0$ \\
\hline & $1 / 8$ & $9.2 \pm 0.8$ & $9.8 \pm 0.8$ & $17.3 \pm 1.2$ & $15 \pm 0$ & $9.3 \pm 0.6$ & $8 \pm 1.7$ & $7.7 \pm 1.2$ & $19.7 \pm 0.6$ \\
\hline \multirow{4}{*}{ Rasselmiad } & 1 & $23 \pm 0$ & $16 \pm 1.7$ & $23 \pm 1.7$ & $20 \pm 0$ & 0 & $26 \pm 0$ & $15 \pm 0$ & $35.7 \pm 1.2$ \\
\hline & $1 / 2$ & $20.3 \pm 0.6$ & $14.2 \pm 0.3$ & $14.3 \pm 0.6$ & $16 \pm 0$ & 0 & $13 \pm 0$ & $13 \pm 0.8$ & $28 \pm 0$ \\
\hline & $1 / 4$ & $12 \pm 0$ & 0 & $11.3 \pm 0.6$ & $10 \pm 0$ & 0 & $12.5 \pm 0$ & $10 \pm 0$ & $20.3 \pm 0.6$ \\
\hline & $1 / 8$ & $8 \pm 0$ & 0 & $8.3 \pm 0.5$ & 0 & 0 & $9.3 \pm 1.2$ & $7.3 \pm 0.6$ & $11.7 \pm 0.3$ \\
\hline \multirow{4}{*}{ In Aminaas } & 1 & $16 \pm 0.5$ & $10 \pm 0$ & $20 \pm 00$ & 0 & $23.8 \pm 1$ & $35.3 \pm 0.6$ & $12 \pm 0.5$ & $34.3 \pm 0.6$ \\
\hline & $1 / 2$ & $11 \pm 0$ & 0 & $12.8 \pm 0.6$ & 0 & $18 \pm 0$ & $28 \pm 0.9$ & 0 & $22.8 \pm 0.6$ \\
\hline & $1 / 4$ & $9.8 \pm 0.3$ & 0 & $10 \pm 0$ & 0 & 0 & $18.2 \pm 1.4$ & 0 & $17.6 \pm 0.6$ \\
\hline & $1 / 8$ & $9 \pm 0$ & 0 & $7.5 \pm 0.5$ & 0 & 0 & $10.7 \pm 1.2$ & 0 & $13 \pm 0$ \\
\hline \multirow{4}{*}{ Dabdaab } & 1 & $20 \pm 0$ & $12.7 \pm 0.2$ & $18.7 \pm 0.6$ & 0 & 0 & $10.8 \pm 0.3$ & $14.7 \pm 1.2$ & $29 \pm 0$ \\
\hline & $1 / 2$ & $15.3 \pm 0.3$ & 0 & $12 \pm 0$ & 0 & 0 & $7.8 \pm 1$ & $9 \pm 0$ & $20 \pm 0$ \\
\hline & $1 / 4$ & $11.9 \pm 0.2$ & 0 & 0 & 0 & 0 & 0 & 0 & $17 \pm 0$ \\
\hline & $1 / 8$ & $7.7 \pm 1.2$ & 0 & 0 & 0 & 0 & 0 & 0 & $13 \pm 0$ \\
\hline \multirow{4}{*}{ Oulad Slimane } & 1 & $11.2 \pm 0.3$ & 0 & $27.2 \pm 0.3$ & $25.3 \pm 0.6$ & $14.4 \pm 0.1$ & $19.7 \pm 1.2$ & $20 \pm 0$ & $54.8 \pm 1.1$ \\
\hline & $1 / 2$ & $8 \pm 0$ & 0 & $17 \pm 0$ & $21.2 \pm 0.3$ & $13.8 \pm 0.3$ & $14 \pm 0$ & $16 \pm 0$ & $31 \pm 0$ \\
\hline & $1 / 4$ & 0 & 0 & $14 \pm 0$ & $13 \pm 0$ & 0 & $11.7 \pm 1.2$ & $11 \pm 0$ & $21 \pm 0$ \\
\hline & $1 / 8$ & 0 & 0 & $10 \pm 0$ & 0 & 0 & $10 \pm 0$ & 0 & $12 \pm 0$ \\
\hline \multirow{4}{*}{ Boussaâda } & 1 & $14.2 \pm 0.3$ & $10 \pm 0$ & $20 \pm 0$ & $17 \pm 0$ & 0 & 0 & $21 \pm 0$ & $31.7 \pm 2.9$ \\
\hline & $1 / 2$ & $10.7 \pm 0.6$ & $9 \pm 0$ & $15.7 \pm 0.6$ & $14.3 \pm 0.6$ & 0 & 0 & $13 \pm 0$ & $20 \pm 0$ \\
\hline & $1 / 4$ & 0 & 0 & $12.2 \pm 0.3$ & $11 \pm 0$ & 0 & 0 & $12 \pm 0$ & $16 \pm 0$ \\
\hline & $1 / 8$ & 0 & 0 & $10.3 \pm 0.6$ & $8.3 \pm 0.6$ & 0 & 0 & $10 \pm 0$ & $13 \pm 0$ \\
\hline \multirow{4}{*}{ EL Menea } & 1 & $19 \pm 0$ & $12 \pm 0$ & $26 \pm 0$ & $20 \pm 0$ & $23 \pm 1.2$ & $24 \pm 0$ & $19.8 \pm 0.3$ & $51.1 \pm 0.2$ \\
\hline & $1 / 2$ & $12 \pm 0$ & $10.7 \pm 0.6$ & $18 \pm 0$ & $16 \pm 0$ & $14.7 \pm 0.3$ & $16.5 \pm 0.9$ & $13 \pm 0$ & $30 \pm 0$ \\
\hline & $1 / 4$ & $10 \pm 0$ & $8.3 \pm 0.3$ & $16 \pm 0$ & $12 \pm 0$ & $10 \pm 0$ & $14.4 \pm 0.4$ & $11.3 \pm 1.2$ & $12 \pm 0$ \\
\hline & $1 / 8$ & $8.3 \pm 1.12$ & 0 & $12 \pm 0$ & $9 \pm 0$ & 0 & $11 \pm 0$ & $8 \pm 0$ & $10 \pm 0$ \\
\hline & Gen & $27 \pm 0$ & $28.3 \pm 0.6$ & $22 \pm 0$ & $23 \pm 0$ & $20 \pm 0$ & $29 \pm 0$ & 0 & $40.3 \pm 0.6$ \\
\hline & CZ30 & $29.3 \pm 0.6$ & 0 & $19 \pm 0$ & 0 & $18 \pm 0$ & 0 & 0 & $34.7 \pm 0.6$ \\
\hline Antibiotic standard & Amo & $26 \pm 0$ & 0 & $31.3 \pm 0.6$ & $30.7 \pm 0.6$ & 0 & $30.3 \pm 0.5$ & $17.3 \pm 1.5$ & $35.3 \pm 0.6$ \\
\hline & CL25 & $17.3 \pm 0.5$ & $18.3 \pm 0.6$ & 0 & 0 & $19.7 \pm 0.6$ & $13 \pm 0$ & $20 \pm 0$ & $21 \pm 0$ \\
\hline
\end{tabular}


Table 6. Main effects and interactions of essential oils of Matricaria pubescens

\begin{tabular}{|c|c|c|c|}
\hline Source & df & $\mathbf{F}$ & $\mathbf{P}$ \\
\hline \multicolumn{4}{|l|}{ Main effects } \\
\hline Sampling locations & 13 & 30.24 & $.0000 * * *$ \\
\hline Dilution level & 7 & 731.28 & $.0000 * * *$ \\
\hline Species of bacteria & 7 & 626.92 & $.0000 * * *$ \\
\hline \multicolumn{4}{|l|}{ Interaction } \\
\hline Sampling locations $*$ Doses & 91 & 5.80 & $.0000 * * *$ \\
\hline Sampling locations $*$ Bacteria & 91 & 8.84 & $.0000 * * *$ \\
\hline Dilution level $*$ Bacteria & 49 & 151.87 & $.0000 * * *$ \\
\hline $\begin{array}{l}\text { Sampling locations } * \text { Dilution } \\
\text { level } * \text { Species of bacteria }\end{array}$ & 637 & 3.27 & $.0000 * * *$ \\
\hline
\end{tabular}

Table 8. Sensitivity groups of tested bacteria to the essential oils of Matricaria pubescens

\begin{tabular}{|c|c|c|c|c|c|}
\hline $\operatorname{Ran}$ & Species of bacteria & $\begin{array}{c}\text { Mean } \\
\text { inhibition } \\
\text { zones }(\mathbf{m m})\end{array}$ & Si & $\begin{array}{l}\text { Significant } \\
\text { groups }\end{array}$ & $\mathbf{S}^{*}$ \\
\hline 1 & P. mirabilis ATCC 35659 & 27.45 & $336 \mathrm{a}$ & & +++ \\
\hline 2 & E. coli ATCC25922 & 17.99 & 336 & $\mathrm{~b}$ & ++ \\
\hline 3 & S. aureus ATCC25923 & 17.69 & 336 & $\mathrm{~b}$ & ++ \\
\hline 4 & L. іппосиа CLIP 74915 & 16.65 & 336 & $\mathrm{c}$ & ++ \\
\hline 5 & K. pneumoniae ATCC700603 & 11.93 & 336 & $\mathrm{~d}$ & + \\
\hline 6 & B. cereus ATCC 11778 & 11.31 & 336 & $\mathrm{~d}$ & + \\
\hline 7 & S. enterica CIP81-3 & 10.19 & 336 & $\mathrm{e}$ & + \\
\hline 8 & P. aeruginosa ATCC 27853 & 9.44 & 336 & $\mathrm{f}$ & + \\
\hline
\end{tabular}

Note: LSD $0.05=0.66217084683 ; * \mathrm{~S}=$ Sensitivity (++ highly significant $(\mathrm{P}<0.01)$; + Significant $(\mathrm{P}<0.05)$
Table 7. Effect of oil dilutions on the inhibitory zone of tested bacteria

\begin{tabular}{|c|c|c|c|c|}
\hline Rank & Doses & $\begin{array}{c}\text { Mean inhibition } \\
\text { zones (mm) }\end{array}$ & $\mathbf{n}$ & Significant groups \\
\hline 1 & Gentamicine & 24.07 & 336 & $\mathrm{a}$ \\
\hline 2 & Amoxicilline & 21.36 & 336 & $\mathrm{~b}$ \\
\hline 3 & Dilution 1/1 & 20.85 & 336 & $\mathrm{~b}$ \\
\hline 4 & Colistine 25 & 15.39 & 336 & $\mathrm{c}$ \\
\hline 5 & Dilution 1/2 & 14.09 & 336 & $\mathrm{~d}$ \\
\hline 6 & Cefazoline 30 & 12.55 & 336 & $\mathrm{e}$ \\
\hline 7 & Dilution 1/4 & 8.87 & 336 & $\mathrm{f}$ \\
\hline 8 & Dilution 1/8 & 5.45 & 336 & $\mathrm{~g}$ \\
\hline
\end{tabular}

Note: LSD $0.05=0.66217084683$
Table 9. The effectiveness of Matricaria pubescens essential oils from several sampling locations against eight bacteria species

\begin{tabular}{llllllll}
\hline Rank & $\begin{array}{l}\text { Sampling } \\
\text { location }\end{array}$ & $\begin{array}{c}\text { Mean } \\
\text { inhibition } \\
\text { zones }(\mathbf{m m})\end{array}$ & n & \multicolumn{2}{c}{$\begin{array}{c}\text { Significant } \\
\text { groups }\end{array}$} \\
\hline 1 & Djamaa & 18.55 & 192 & a & & & \\
2 & Magrane & 17.92 & 192 & a & & & \\
3 & Bakaar & 16.60 & 192 & b & & \\
4 & El Menea & 16.37 & 192 & bc & & \\
5 & Mihouansa & 15.97 & 192 & bcd & & \\
6 & Rass Elmiad & 15.67 & 192 & & cd & \\
7 & Hassi Khalifa & 15.56 & 192 & & cd & \\
8 & Ben Nacer & 15.23 & 192 & & & d & \\
9 & Oulad Slimane & 15.21 & 192 & & & d & \\
10 & In Aminaas & 14.23 & 192 & & & & e \\
11 & El m'ghair & 14.05 & 192 & & & & e \\
12 & Beni Guecha & 13.45 & 192 & & & & e \\
13 & Boussaâda & 13.44 & 192 & & & & e \\
14 & Dabdaab & 12.35 & 192 & & & & f \\
\hline
\end{tabular}

Note: LSD $0.05=0.87596969307$

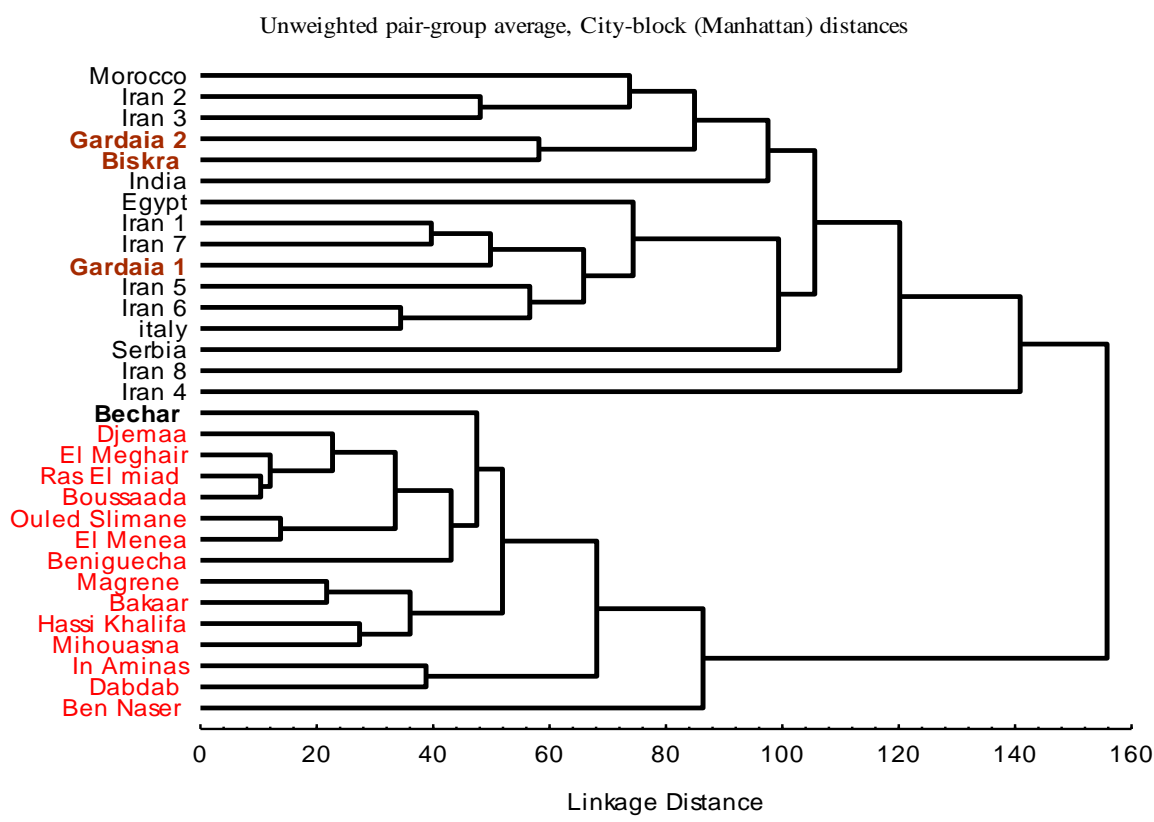

Figure 8. UPGMA of Matricaria pubescens and M. chamomilla populations 
Amoxicillin and undiluted essential oils of $M$. pubescens, have the same inhibitory effect on the bacteria tested, with average diameters of inhibitory zone of 21.36 and $20.85 \mathrm{~mm}$ respectively, and classified in the group b. The antibacterial activity of diluted essential oils (1/4 and 1/8) was very weak to no-antibacterial activity, with the diameter of growth inhibition of 8.87-5.45mm.

The results reveal that $P$. mirabilis is highly sensitive to the essential oils of $M$. pubescens, it is classified in the group a, with average growth inhibition of $27.45 \mathrm{~mm}$ (Table 8 ), while $P$. aeruginosa was the least sensitive to $M$. pubescens oils, with average growth inhibition of $9.44 \mathrm{~mm}$.

Djamaa and Magrane populations were classified in the group a, with average growth inhibitions of 18.55 and $17.92 \mathrm{~mm}$, respectively. The essential oils of these populations have the best antibacterial activities (Table 9), while the essential oil of the population of Dabdaab has the lowest antibacterial activity to the majority of bacteria tested. It is classified in the last group (f) with an average inhibition diameter of $12.35 \mathrm{~mm}$.

\section{Discussion}

The yields of essential oils of the studied populations of M. pubescens are variable and low, ranging from 0.06 to $1.03 \%$. These values are similar to the yields reported in the literature. A study conducted by Boutaghane et al. (2011) on the same species in the Ghardaia region showed $1.2 \%$ essential oils. Makhloufi et al. (2012) reported that the essential oil content on Bechar populations was $0.8 \%$; while the hydro distillation of samples from Biskra region had a low yield of $0.17 \%$ (Bouzaine 2014). The yield differences in essential oils of the populations of the same species can be explained by the origin of species population, harvest period, plant organ, drying time, and extraction method (Vekiari et al. 2002; Karousou et al. 2005).

The chemical composition of essential oils of $M$. pubescens populations in this study was different from those of the samples in previous studies. Ghardaia populations were characterized by ethyl isochrysanthemoate, spathulenol, $\alpha$-cadinol, and geranylisovalerate (Boutaghane et al. 2011; Tadrent et al. 2016). Other populations in the Ghardaia region showed the presence of endobornyl acetate and sapathulenol (Bouzaine (2015),. The essential oil of the Biskra populations were composed of spathulenol, elemicine, and herniarine (Bouzaine 2015). On the other hand, the populations of Bechar (Makhloufi et al. 2014) showed a similarity in the chemical composition with that of populations in this study.

Statistical analysis (UPGMA) was used to distinguish between two species of Matricaria (M. pubescens and $M$. chamomile), which were morphologically and geographically very similar (Figure 8). The result of the UPGMA analysis showed that there were two separate groups. The first group included the populations in this study, and that of Bashar belongs to M. pubescens. The second group included the populations of Biskra (Tadrent et al. 2016) and that of Ghardaia (Bouzaine 2014, 2015;
Tadrent et al. 2016), belongs to M. chamomilla. It is quite possible that specimens of Algerian populations studied by Boutaghane et al. (2011), Bouzaine (2015), and Tadrent et al. (2016) belonged to $M$. chamomilla.

The essential oils of $M$. pubescens exerted a significant inhibition to Gram + and Gram-bacteria. The same findings were unveiled in the study of Makhloufi et al. (2012) on $M$. pubescens essential oils from the Bechar region. However, the essential oils of $M$. pubescens from Ghardaia and Biskra regions showed no antibacterial activity (Bouzaine et al. 2011). The antibacterial activity of $M$. pubescens essential oils in this study was consistent with the work of Abu-Darwish et al. (2012). The antibacterial activity of $M$. pubescens varies greatly. The antimicrobial properties of essential oils are related to their chemical composition. The sensitivity of a microorganism to the essential oil depends mainly on its major compound; the synergistic or antagonistic effect of each of its constituents present in low content is also considered (Kalemba and Kunicka 2003).

In conclusion, the analysis of the essential oils of Matricaria pubescens populations by CPG / MS made it possible to identify 34 components. The main components were $\beta$-ocimene $(\mathrm{Z}), \alpha$-pinene), and $\beta$-bulnesene. The chemical compounds of $M$. pubescens of the populations studied showed a notable difference with an abundance of hydrocarbon monoterpenes. This difference allowed us to identify four chemotypes ( $\alpha$-bulnesene- $\beta$-ocimane (Z)- $\alpha$ pinene); ( $\alpha$-pinene- $\beta$-ocimane-Ocimene allo); ( $\alpha$-pinene- $\beta$ ocimane (Z)-1-phenyl-penta-2,4-diyne) and the chemotype to ( $\alpha$-pinene- $\beta$-ocimane ( $Z$ )-caryophyllene oxide). The bacterial species tested were susceptible to the essential oils of M. pubescens.

\section{REFERENCES}

Abu-Darwish MS, Al-Ramamne EAM, Kyslychenk VS, and Karpiuk UV. 2012. The antimicrobial activity of essential oils and extracts of some medicinal plants grown in Ashshoubak region-South of Jordan Pak. J Pharm Sci 25 (1): 239-246.

Adams RP. 2007. Identification of Essential Oil Components by Gas Chromatography/Mass Spectrometry. 4th Edition Allured Publishing Corporation, Carol Stream, Illinois USA.

Benhouhou S. 2005. Aaronsohnia pubescens (Dasf.) K. Bremer \& Humphries. In A guide to medicinal plants in North Africa. IUCN Centre for Mediterranean Coorporation, Malaga, Spain.

Benkiki N. 2006. Etude phytochimique des plantes médicinales algérienne, Ruta montana, Matricaria pubescens et Hyperium perjoliatum. Thèse de Doctorat, Université Al-Hadj Lakhdar Batna, Algeria. [France]

Bouallala M, Chehma A. 2014. Biodiversity and phytogeography of Saharan ecosystems of the region Taghit (Bechar). Algerian J Arid Environ 4 (1): 39-44.

Boutaghane N, Kabouche A, Touzanib R, Maklad YA, El-Azzounyb A, Bruneaud C, Kabouche Z. 2011. GC/MS analysis and analgesic effect of the essential oil of Matricaria pubescens from Algeria. Nat Prod Commun 6 (2): 251-252. DOI: 10.1177/1934578X1100600224

Bouzaine M, Hadj-mahammed M, Amirate M, Debakh O, Naghmouch Salah A. 2011. Analyse qualitative par GC-FID de l'huile essentielle de la plante Matricaria pubescens et evaluation de son action biologique. 2ème Séminaire International sur les Plantes Médicinales SIPM'2 Ouargla.[France]

Bouzaine M, Hadj-Mahammed M, Dehak K, Oussameur N, Ksikis C, Benzaoui F, Houari A. 2016. Antioxidant and antibacterial properties of Brocchia cinerea (Vis.) and Matricaria pubescens (Desf.) ethyl 
acetate extracts and their fractions. Der Pharma Chemica 8 (17): 232239.

Bouzaine M. 2015. Extraction et analyse de la composition chimique de plantes sahariennes d'intérêt médicinal. Thèse de Doctorat, Université Kasdi-Merbah, Ouargla, \{France $]$

Dahiya P, Purkayastha S. 2012. Phytochemical screening and antimicrobial activity of some medicinal plants against multi-drug resistant bacteria from clinical isolates. Indian J Pharm Sci 74 (5): 443-450. DOI: 10.4103/0250-474X.108420

Deschepper R. 1990. Variabilité de la composition des huiles essentielles et intérêt de la notion de chémotype en aromathérapie. Thèse de Doctorat d'Etat en Pharmacie, Université d'Aix Marseille, France, 172p. https://dumas.ccsd.cnrs.fr/dumas-01515314/document

Djellouli M, Moussaoui A, Benmehdi H, Ziane L, Belabbes A, Badraoui M, Slimani N, Hamidi N. 2013. Ethnopharmacological studyand phytochemical screening of three plants (Asteraceae Family) from the region of South West Algeria. Asian J Nat Appl Sci 2 (2): 62-64. https://pdfs.semanticscholar.org/561d/61d2abc05e0fc10a2b22632ef90 cd7f6c55f.pdf

Gherboudj O, Benkiki N, Seguin E, Tillequin F, Kabouche Z. 2012. Components of Matricaria pubescens from Algerian septentrional Sahara. Chem Nat Compd 48 (3): 470-471. DOI: 10.1007/s10600012-0277-2

Hammiche V, Maiza K. 2006. Traditional medicine in Central Sahara: Pharmacopoeia of Tassili N'ajjer. J Ethnopharmacol 105: 358-367. DOI: $10.1016 /$ j.jep.2005.11.028

Kalemba D, Kunicka A. 2003. Antibacterial and antifungal properties of essential oils. Current Medicinal Chemistry. 10 (10):813-29. DOI: $10.2174 / 0929867033457719$

Karousou R, Koureas DN, Kokkini S. 2005. Essential oil composition is related to the natural habitats: Coridothymus capitatus and Satureja thymbra in NATURA 2000 sites of Crete. Phytochemistry 66: 26682673. DOI: 10.1016/j.phytochem.2005.09.020

Maiza K, RA Brac de la Perrière, Hammiche V. 1995. Pharmacopée traditionnelle saharienne. Revue de Médecines et Pharmacop Afr 9 (1): 71-75. [France]

Maiza K, Hammiche V, Maiza F. 2011. Traditional medicine in north Sahara. Rev Méd Pharmacop Afr 16 (1): 0976-1098.
Makhloufi A, Bouyahyaoui N, Seddiki N, Benlarbi L, Mebarki L, Boulanouar A. 2014. Chemical composition and antifungal activity of Aaronsohnia pubescens essential oil from Algeria. Int J Phytoth 4 (2): 95-100. DOI: 10.1177/1934578X1501000134

Makhloufi A, Moussaoui A, Lazouni HA. 2012. Antibacterial activities of essential oil et crude extracts from Matricaria pubescens (Desf.) growing wild in Bechar, Southwest of Algeria. J Med Plants Res 6 (16): 3124-3128. DOI: 10.5897/JMPR11.1367

Masada Y. 1976. Analysis of essential oils by gas chromatography and mass spectrometry. Halsted, New York.

Metrouh-Amir H, Duarte CM, Maiza F. 2015. Solvent effect on total phenolic contents, antioxidant, and antibacterial activities of Matricaria pubescens. Ind Crops Prod 67: 249-256. DOI: 10.1016/j.indcrop.2015.01.049

NIST. 2002. Mass spectral search program for the NIST/EPA/NIH mass spectral library, vers. 2.0. fiveash data. USA.RP. https://dx.doi.org/10.1021/ac301205z

Ould el Hadj MD, Hadj-Mahammed M, Zabeirou H. 2003. Place of the spontaneous plants samples in the traditional pharmacopoeia of the area of Ouargla (septentrional east Sahara). Courrier du Savoir 03: $50-51$.

Ozenda P. 2004. Flore et Végétation du Sahara. Troisième édition. Ed. CNRS, Paris (92): 438-662. [France]

Ponce AG, Fritz R, del Valle C, Roura SI. 2003. Antimicrobial activity of essential oils on the native microflora of organic Swiss chard. LWTFood Sci Technol 36 (7): 679-684. DOI: 10.1016/S0023-6438 (03)00088-4

Quézel P et Santa S. 1963. Nouvelle Flore de l'Algérie et des régions désertiques méridionales. Vol. 1-2, Ed. CNRS, Paris, France. [France]

Reyes-Betancort JA, Scholz S, Arencibia MCL. 2003. About the presence of the Moroccan endemic Aaronsohnia pubescens subsp. maroccana in the Canary Islands (Anthemidae, Asteraceae). Vieraea 31: 233-236.

Tadrent W, Kabouche A, Touzani R, Kabouche Z. 2016. Chemotypes investigation of essential oils of Chamomile herb. J Mater Environ Sci 7 (4): 1229-1235.

Vekiari SA, Papadopoulou P, Koutsaftakis A. 2002. Comparison of different olive oil extraction systems and the effect of storage conditions on the quality of the virgin olive oil. Grasas Aceites 53 (3): 324-329. DOI: 10.3989/gya.2002.v53.i3.324 